\title{
Science and Medicine in Tropical Africa
}

A Central African Scientific and Medical Congress was held at Lusaka, Zambia, 26-30 August 1963. The proceedings have recently been published under the title of Science and Medicine in Tropical Africa, edited by J. Snowball, pp. 980, Pergamon Press (Oxford and New York), 1965. The papers are presented in four sections: Physical Sciences, including geology, meteorology, and engineering; Biological Sciences, including agriculture; Social Sciences, including archaeology; Medical Sciences.

\section{Bibliography of Madagascar}

A NEw bibliography-Madagascar and Adjacent Islands: A Guide to Official Publications-has been published by the Library of Congress, the eleventh in the Library's series of guides to documents issued by the various African governments. The 58-page paperbound list is available at 40 cents a copy from the Superintendent of Documents, U.S. Government Printing Office, Washington, D.C. 20402.

Compiled in the African Section of the Library's General Reference and Bibliography Division by Julian W. Witherell, the new guide contains 927 entries listing publications of French administrations in Madagascar, the Comoro Islands, and Réunion, those of British administrations in Mauritius and Seychelles, and a selection of material issued by France and Great Britain relating to their respective territories. The terminal date for entries in the Madagascar section is October 1958, the date of the establishment of the Malagasy Republic; for the other islands, entries have been continued to 1964 .

Under each dependency, entries are arranged alphabetically by author and title, except that census reports and material on development planning are grouped by subject. An index provides a key to authors and subjects.

\section{The Historical Society of Nigeria: Eleventh Annual Congress}

THE Eleventh Annual Congress of the Historical Society of Nigeria was held on 19, 20, and 21 December 1965 in the Abdullahi Bayero College, Kano, by kind permission of the Provost. Papers presented and discussed included: the 1964 excavation at Igbo-Uku (Professor T. Shaw); archaeological field research in Bornu 1964-5 (G. E. Connah); Islamic historiography with special reference to West Africa (J. O. Hunwick); the Oyo Empire in the eighteenth century (Dr. I. A. Akinjogbin); the Imamate question in the Western Region of Nigeria (P. G. O. Gbadamosi); the missionary factor in Northern Nigeria, 1870-1918 (Dr. E. A. Ayandele); the origins of the West African Frontier Force (S. C. Ukpabi); from 'Direct' to 'Indirect Rule' in Benin I897-1920 (P. A. Igbafe); the freed slaves' homes -an unknown aspect of northern Nigerian social history (Dr. G. O. Olusanya); the background to trade union movement in Nigeria (E. O. Egboh); the anti-tax riot in Warri Province 1927-8 (Dr. O. Ikime).

\section{International Student Movement for the United Nations: 1966 International Seminar}

THE 1966 International Seminar of ISMUN is being held at Christ's College, Cambridge, from 24 to 30 March 1966, on 'African Development and Europe'. The Seminar will conduct its work in two sections: in Plenary Sessions the participants will hear addresses on the following subjects: The African agricultural revolution; the establishment of an industrial complex; manpower and management in the strategy of industrial development; the trading revolution in Europe and Africa; development-the administrative problem. 